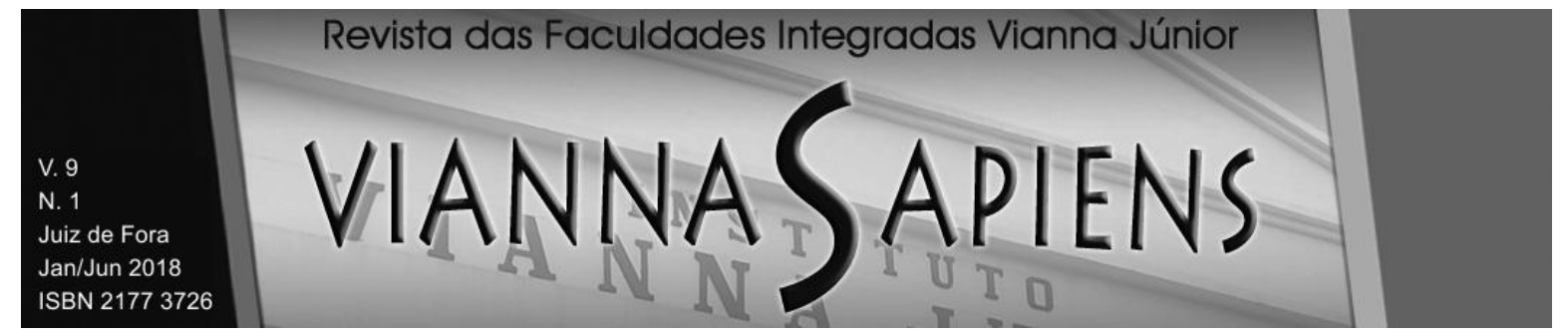

\title{
ÁGUA (ODS 6), PROGRAMA CISTERNAS E O NOVO REGIME FISCAL BRASILEIRO
}

DOI: 10.31994/rvs.v9i1.277

Thanderson Pereira de Sousa ${ }^{1}$

\section{RESUMO}

Analisa-se nesse estudo a configuração da água como direito fundamental do cidadão, o Programa Cisternas como instrumento de concretização do dito direito no semiárido brasileiro e a relação entre o novo regime fiscal e a política pública de acesso à água. $O$ objetivo consiste na identificação dos reflexos do novo regime fiscal vigente no Programa Cisternas. Utiliza-se método predominantemente qualitativo, contando com técnicas de pesquisa bibliográfica e documental, além de análise quantitativa dos orçamentos da União entre 2013 e 2018. Infere-se que o Programa Cisternas, a depender das escolhas de alocação de recursos na Lei Orçamentária Anual, dentro do novo regime fiscal, poderá ser fragilizado, prejudicando os avanços na promoção do acesso à água por famílias pobres da zona rural no semiárido brasileiro.

PALAVRAS-ChAVE: ÁGUA. PROGRAMA CISTERnAS. ORÇAMENTO. NOVO REGIME FISCAL.

\footnotetext{
${ }^{1}$ Mestrando pelo Programa de Pós-Graduação em Direito da Universidade Federal do Ceará - UFC (Bolsista CNPq). Bacharel em Direito pelo Instituto Camilo Filho - ICF. Integrante do grupo de pesquisa Serviços públicos e condições de efetividade (UFC e UFPR). Pesquisa na área de Direito Constitucional, dedicando-se às seguintes temáticas: jurisdição constitucional, separação dos poderes, direitos sociais e ordens tributária e financeira. http://orcid.org/0000-0003-0725-3572
} 


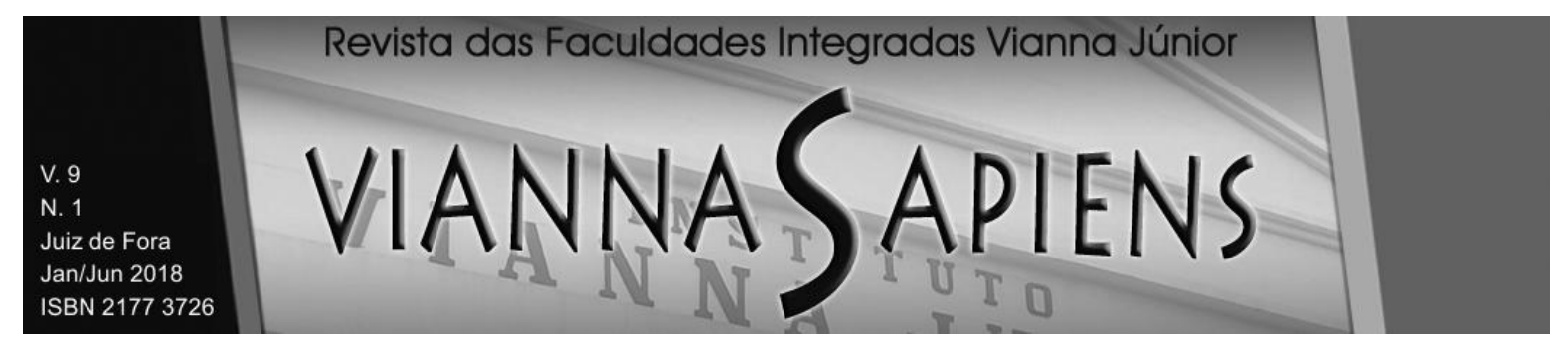

\section{INTRODUÇÃO}

Este estudo busca tratar da promoção do acesso à água (ODS 6) por famílias pobres do Semiárido brasileiro a partir do Programa Cisternas, e, os possíveis impactos do novo regime fiscal, instituído pela Emenda Constitucional ํㅜ 95, que limita as despesas primárias da União.

A problemática que impulsiona a pesquisa realizada centra-se no questionamento de haver ou não possibilidades de o novo regime fiscal representar um risco para o Programa Cisternas, política pública que amplia o acesso à água para consumo humano e produção no Semiárido.

A justificativa do estudo se fundamenta na importância de se buscar o desenvolvimento sustentável, conforme a Constituição de 1988 e as disposições da Agenda 2030 da ONU. O acesso à água é um dos pressupostos para o desenvolvimento, constituindo, inclusive, um Objetivo de Desenvolvimento Sustentável (ODS), que não pode ser desprezado pela atividade financeira do Estado, pois, contribui para a erradicação da pobreza, diminuição das desigualdades, alimentação, queda de mortalidade infantil, entre outros. É inquestionável que a ciência jurídica deve discutir os rumos da relação entre acesso à água, orçamento e regime fiscal.

A abordagem metodológica empregada na realização desta investigação é preponderantemente qualitativa, contando com técnicas bibliográfica e documental, além de quantitativamente analisar as leis orçamentárias anuais de 2013 a 2017, e, o Projeto de Lei Orçamentária de 2018 da União.

O texto estrutura-se em três tópicos. No primeiro, é abordada a configuração da água enquanto um direito fundamental; no segundo, o Programa Cisternas é concebido enquanto política pública para acesso à água; e, por último, é debatida a relação entre o financiamento do Programa Cisternas e o novo regime fiscal brasileiro.

Infere-se dos resultados obtidos que o Programa Cisternas, dependendo das escolhas feitas na alocação de recursos - dentro da lei orçamentária anual, poderá 


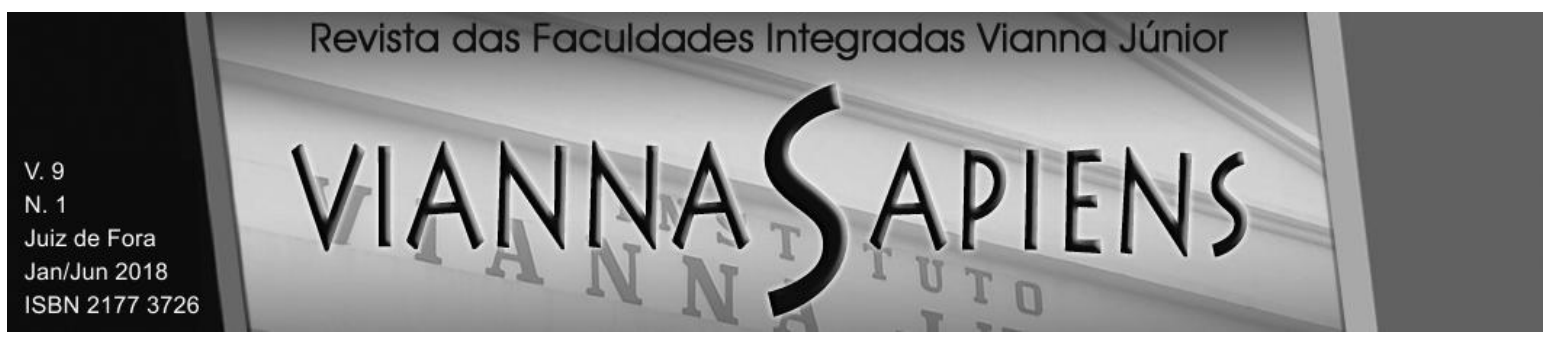

ser fragilizado, uma vez que, em função da inexistência de aumento real no orçamento, o Executivo federal deve fazer escolhas e estabelecer prioridades, que pela leitura do PLOA 2018 não contemplaram o Programa de Segurança Alimentar, e, consequentemente o Programa Cisternas, refletindo então negativamente na promoção do acesso à água e concretização da Agenda 2030 no Brasil.

\section{CONFORMAÇÃO DO DIREITO FUNDAMENTAL DE ACESSO À ÁGUA}

A Constituição de 1988 inaugura no cenário brasileiro um novo modelo de estado, o social, a seu turno preocupado com as condições materiais necessárias à dignidade humana e exercício efetivo dos direitos fundamentais (BONAVIDES, 2013). As disposições constitucionais eliminaram do ordenamento o domínio privado das águas, nos casos previstos pelo Código de Águas de 1934, tornando clara a orientação no sentido da democratização dos recursos hídricos, "são públicos os bens do domínio nacional pertencentes às pessoas jurídicas de direito público interno" (MATIAS, 2016, p. 352), o que por sua vez inclui a água.

Partindo de uma premissa sistemática de interpretação constitucional, em que a norma interpretada deve consideração a todas as demais (SAVIGNY, 1949), e conjugando os artigos 3ำ, 170, VI e 225 da Constituição de 1988, é perceptível a opção que o legislador constituinte fez pelo desenvolvimento sustentável, combinando os aspectos econômico, social e ambiental enquanto pressupostos para o desenvolvimento nacional.

Ana Cláudia Finger (2014) ratifica esse entendimento, asseverando ainda que o desenvolvimento sustentável é uma norma constitucional de caráter principiológico. Desta feita, do princípio constitucional ao desenvolvimento sustentável decorrem direitos, como os direitos ao meio ambiente sadio e equilibrado e de acesso à água.

O direito de acesso à água está implícito no texto da Constituição, pois, em que pese não existir disposição explícita e específica, a cláusula de abertura 


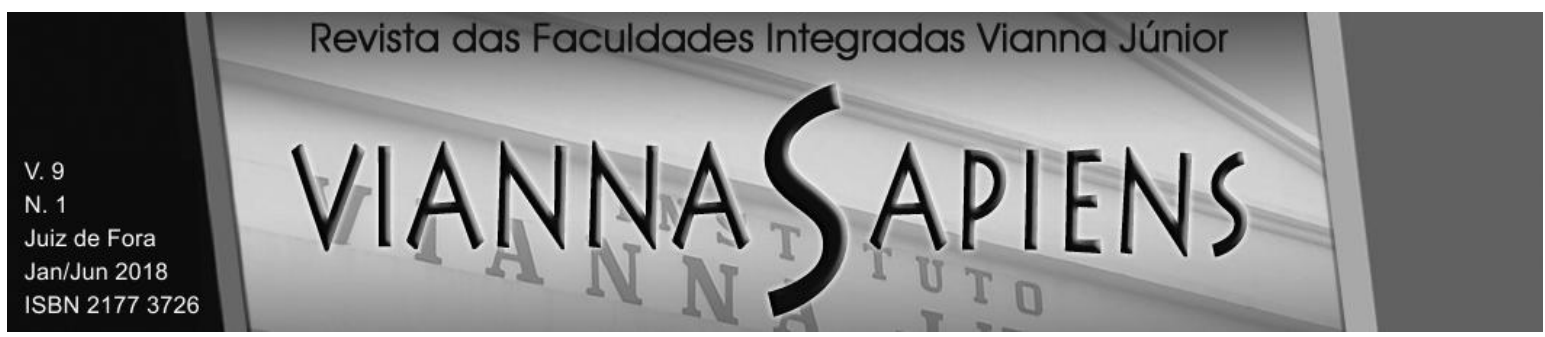

material, prevista no artigo 5으 $\S 2$, determina que "os direitos e garantias expressos [...] não excluem outros decorrentes do regime e dos princípios por ela adotados, ou dos tratados internacionais em que a República Federativa do Brasil seja parte" (BRASIL, 2017, p. 11). É indubitável que do princípio do desenvolvimento sustentável decorre o direito de acesso à água, condição indispensável à sobrevivência e dignidade humana.

Pela interpretação teleológica é necessário alcançar as finalidades de cunho subjacentes à norma que se examina (JHERING, 2002), logo, o acesso à água compõe item que não pode ser desprezado na exegese da Constituição brasileira, se assim for, haverá óbice à proteção da dignidade da pessoa humana e dos demais direitos dela decorrentes.

Ponto da Constituição que reforça a sinalização do acesso à água como direito dos cidadãos é o artigo 21, VXIII, que imputa à União o dever de "planejar e promover a defesa permanente contra as calamidades públicas, especialmente as secas [...]" (BRASIL, 2017, p. 18). Desse modo, a água torna-se ainda mais evidente enquanto um direito, impondo explicitamente ao Poder Executivo federal o deverpoder (BIRNFELD, 2015) de torná-lo acessível para os que necessitam.

No que toca a fundamentalidade do direito à água, são imprescindíveis algumas considerações. Robert Alexy (1999) declara que a identificação de direitos fundamentais depende de três características: (1) universalidade, (2) possibilidade de proteção e fomento pelo direito e (3) a violação ou não observância do direito alcança negativamente o âmago da dignidade humana.

Seguindo o processo de qualificação de fundamentalidade elaborado por Alexy (1999), é perfeitamente possível estremar o direito à água como direito fundamental. Em 2010 resolução da ONU foi aprovada definindo a água como direito de todo ser humano, portanto, universal; o direito pátrio protege e fomenta as águas - Constituição de 1988 e Política Nacional de Recursos Hídricos; e, a não obtenção de água inviabiliza direitos inerentes à dignidade do homem, como a alimentação, saúde, lazer e outros mais. Portanto, de todo o exposto, conclusivamente, a água é um direito fundamental. 


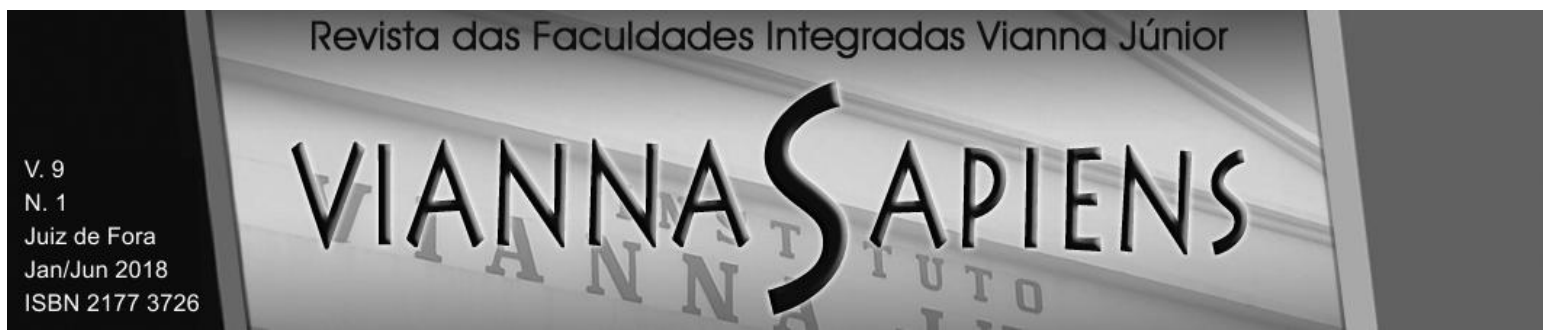

\section{2 ÁGUA (ODS 6), POLÍTICAS PÚBLICAS E O PROGRAMA CISTERNAS}

Restou anteriormente consignado, de forma iniludível, que a água assume caráter de direito fundamental no contexto brasileiro, decorrendo implicitamente das disposições da Constituição de 1988.

No plano infraconstitucional, a Lei ㄲo 9.433 de 1997, que instituí a Política Nacional de Recursos Hídricos, reforçou logo no artigo 1o o caráter público da água, reconhecendo-a com qualidade de recurso natural limitado, determinando como objetivos a (1) garantia da água à atual e às futuras gerações, (2) sua gestão racional e integrada, bem como (3) o incentivo para captação, preservação e aproveitamento.

No ano de 2015, aconteceu em Nova York, na sede da ONU, reunião da Cúpula de Desenvolvimento Sustentável, da qual sobrevieram novos objetivos para o desenvolvimento sustentável - doravante ODS, dando origem a uma nova agenda para o trabalho global dos próximos anos: a Agenda 2030 para o Desenvolvimento Sustentável.

Neste esteio, a água ganha novo status: o de orientação de desenvolvimento sustentável (ODS 6 - Água potável e saneamento). A Agenda 2030, em síntese, estabeleceu 17 ODS's para erradicar a pobreza, gerar bem-estar social, proteger o meio ambiente e o enfrentamento das mudanças climáticas, tudo isso alinhado a um desenvolvimento também de caráter econômico. O desenvolvimento da Agenda pós2015 é conjunto com os governos, a sociedade civil e instituições parceiras.

A água, tal como direito fundamental, e hodiernamente um ODS, deve ser implementada pelo Estado, o que demanda uma atuação governamental comprometida com a execução de políticas públicas econômicas e/ou sociais que de fato permitam o acesso daqueles que precisam da água.

Uma das considerações mais aceita em termos de conceito de políticas públicas é a feita por Thomas Dye (1984), ao concluir que política pública é aquilo que o governo decide fazer ou não, entendendo inclusive que não fazer algo em relação à certa demanda, também é uma configuração de política pública. 


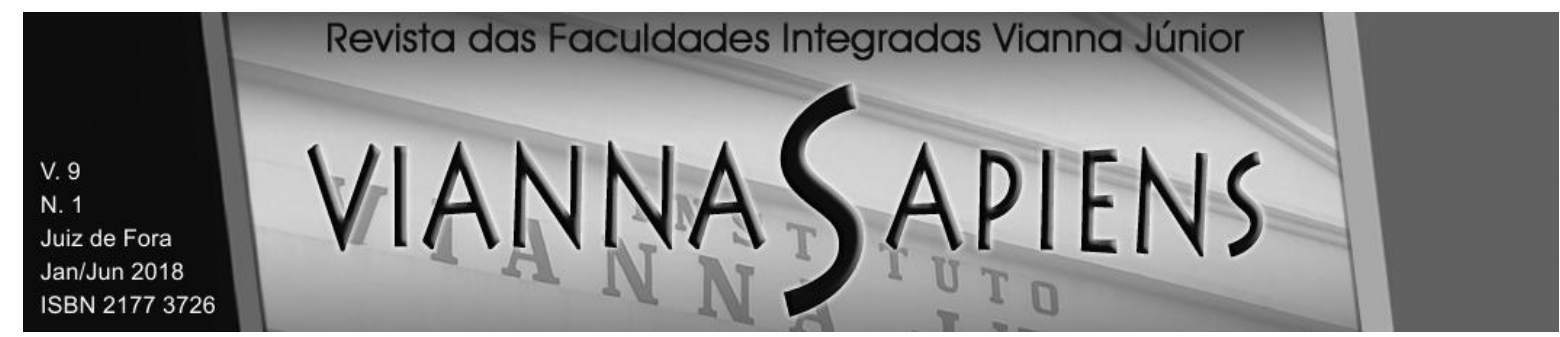

Maria Paula Dallari Bucci (2006, p. 39) descreve política pública como um sistema que sirva de exemplo ao Executivo e Legislativo, propondo o seguinte conceito:

É o programa de ação governamental que resulta de um processo ou conjuntos de processos juridicamente regulados [...] visando coordenar os meios à disposição do Estado e as atividades privadas, para a realização de objetivos relevantes e politicamente determinados.

Do conceito exposto, extraem-se elementos que caracterizam juridicamente uma política pública, quais sejam: o (a) programa, (b) ação-coordenação e o (c) processo. Por programa entenda-se 0 arranjo administrativo para se alcançar determinado resultado. O conteúdo programático de uma política pública deve destacar os objetivos a serem perseguidos, internamente os instrumentos e formas de avaliação, e externamente as ferramentas e procedimentos, além da forma de captação de recursos. A ação-coordenação está ligada à utilização de uma política pública para a consecução de um objetivo determinado previamente (ação) e o alinhamento entre a política pública escolhida e o objeto a ser alcançado (coordenação). Por fim o processo deve ser compreendido com o conjunto de etapas que levam a um fim - a conformação de um direito/alteração do status quo combinado com a participação daqueles que tenham interesse na matéria programática da política pública (BUCCl, 2006).

Diante desta configuração jurídica de políticas públicas, é mister destacar que na área das águas o Governo Federal desde 2003 executava o Programa Nacional de Captação de Águas e Outras Tecnologias Sociais, financiado pelos recursos destinados à Pasta do Desenvolvimento Social.

Mas, foi em 2013 que o Executivo editou a Medida Provisória № 619, convertida na Lei ํㅜ 12.873, instituindo o Programa Cisternas, definindo seu objetivo, âmbito, parceiros, e, prevendo a regulação sobre implementação e execução do programa. Por intermédio do Decreto no 8.038 de 2013, ocorreu a especificação dos 


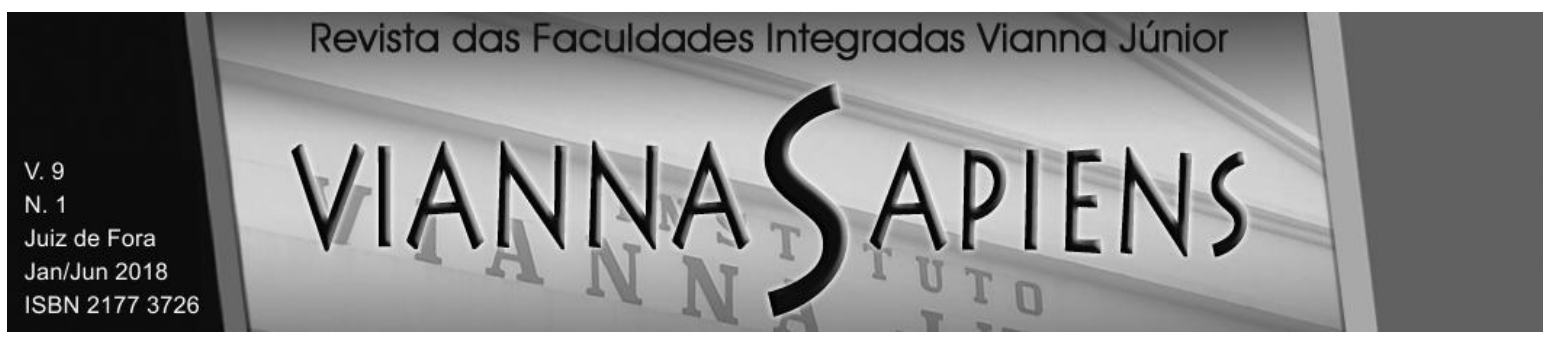

critérios de participação no Programa Cisternas, requisitos para credenciamento dos parceiros e criação do SIG Cisternas (para o controle do programa).

Com a legislação supracitada, torna-se evidente o programa, sendo os arranjos administrativos (meios de implementação, requisitos para credenciamento de parceiros, âmbito do programa, etc.) para o alcance de prévio objetivo (o acesso à água pela população de baixa renda em casos de seca e chuvas irregulares); a ação-coordenação, sendo a utilização do Programa Cisternas para promover o acesso à água, alinhado com as necessidades específicas de implementação do direito fundamental no contexto das famílias de baixa renda da zona rural; e, por fim, o processo, constituído na alteração do status quo: levando água aos que dela necessitam, dando dignidade e condições materiais para sobrevivência, cumprindo os preceitos da Constituição e também o ODS 6, que diretamente concorre para o cumprimento de outros ODS's, como, por exemplo, a erradicação da pobreza (ODS1), fome zero e agricultura sustentável (ODS-2), saúde e bem-estar (ODS-3) e redução das desigualdades (ODS-10).

Destarte, o Programa Cisternas é política pública juridicamente regulada, que organiza os recursos do Estado e sua atuação na concretização do direito fundamental à água, particularmente nos casos das famílias mais pobres das regiões mais secas do Brasil, servindo também - em função da identificação entre o direito fundamental e a ODS-6 - de mecanismo apto para o cumprimento da Agenda 2030 para o Desenvolvimento Sustentável.

\section{PROGRAMA CISTERNAS E NOVO REGIME FISCAL BRASILEIRO}

O objetivo do Programa Cisternas é levar água para consumo e produção até as famílias de baixa renda que são afetadas pela seca, desta forma, a atuação estatal deve dispor de recursos suficientes para alcançar tal objetivo, sob o risco de não agir conforme as disposições constitucionais e não cumprir as metas estabelecidas na Agenda 2030. 


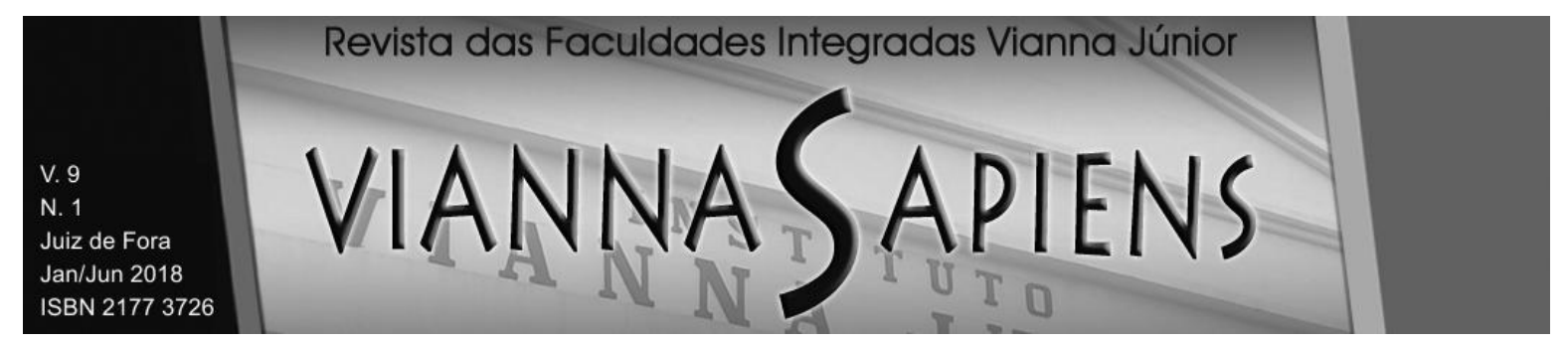

No contexto da água enquanto direito e orientação de desenvolvimento sustentável, o Programa Cisternas demanda investimentos constantes, a ausência de financiamento adequado pode resultar no enfraquecimento não só do direito a água, mas também de todos os demais direitos inerentes ao ser humano e que, direta ou indiretamente, dependem do acesso à água potável.

A concretização de direitos no Estado Social - como é o Brasil - tem custos, Cass Sunstein e Stephen Holmes (2000) observam que as disposições de direitos, sejam negativos ou positivos, dependem da capacidade financeira do Estado em custeá-las, os direitos não nascem por si.

Heleno Torres (2014) explica que não há como limitar os gastos públicos, há neste esteio afinidade com a asserção do referido autor, a própria Constituição de 1988 não vincula um limite máximo aos gastos públicos com valor de referência fincado na arrecadação. Resta então aos Poderes políticos - democraticamente legitimados - fazerem a escolha entre mais investimentos ou uma política de equilíbrio fiscal retraída.

Em 2016, fora encaminhado ao Congresso Projeto de Lei ㄲo 1 de 2016 - CN, revendo as metas orçamentárias, prevendo um déficit de até 96,7 bilhões de reais. $O$ PL ำ1 foi reapresentado, por intermédio da Mensagem ํㅡ 282, alterando a meta do déficit da União para 170,5 bilhões (DIEESE, 2016).

Com o descontrole das contas públicas a presidência da República submeteu Proposta de Emenda à Constituição no 241/2016, objetivando a implantação de um novo regime fiscal, limitando os gastos com despesas primárias - gastos que tornam viáveis prestações de serviços públicos para a sociedade - num longo prazo. A PEC foi aprovada sem grandes dificuldades na Câmara dos Deputados e no Senado, sendo então promulgada - EC no 95 de 2016.

A Emenda Constitucional o 95 de 2016 adicionou ao Ato das Disposições Constitucionais Transitórias - ADCT nove artigos, instituindo o novo regime no âmbito dos orçamentos fiscal e de seguridade social da União (BRASIL, 2017), vigorando para os próximos exercícios financeiros. O artigo 106 do ADCT determina 


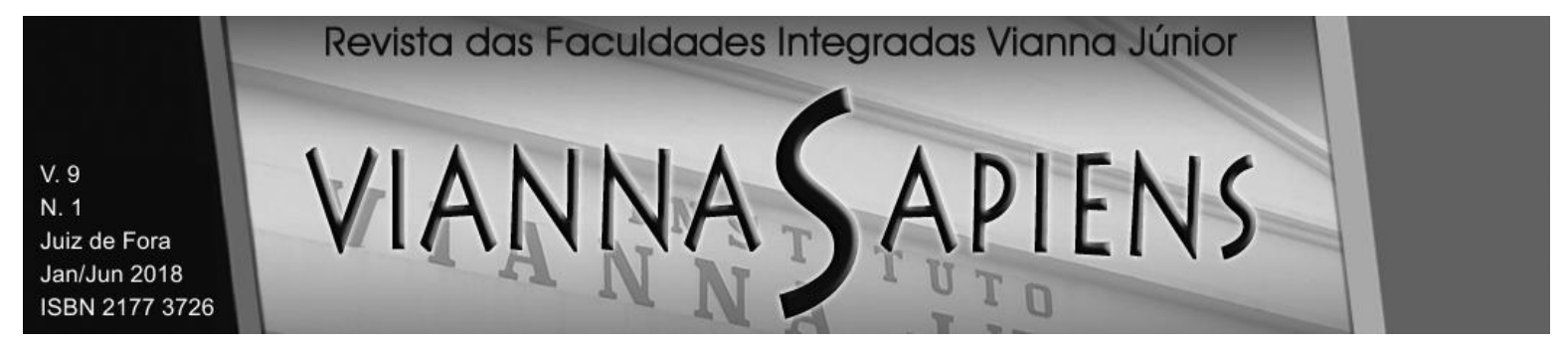

que o regime fiscal instituído pela emenda constitucional vigorará por 20 exercícios financeiros e o art. 107 dispõe:

Ficam estabelecidos, para cada exercício, limites individualizados para as despesas primárias:

I - do Poder Executivo; [...]

$\S 1^{\circ}$ Cada um dos limites a que se refere o caput deste artigo equivalerá:

I - para o exercício de 2017, à despesa primária paga no exercício de 2016, incluídos os restos a pagar pagos e demais operações que afetam o resultado primário, corrigida em 7,2\% (sete inteiros e dois décimos por cento); e

II - para os exercícios posteriores, ao valor do limite referente ao exercício imediatamente anterior, corrigido pela variação do Índice Nacional de Preços ao Consumidor Amplo - IPCA, publicado pelo Instituto Brasileiro de Geografia e Estatística, ou de outro índice que vier a substituí- lo, para o período de doze meses encerrado em junho do exercício anterior a que se refere a lei orçamentária (BRASIL, 2017, p. 231).

A limitação dos gastos, como expresso no artigo, diz respeito somente às despesas primárias, que compreendem a previdência social, gastos com servidores ativos e inativos, e, os gastos sociais, como saúde, educação, agricultura, etc.

Não entram como parte integrante da base para o cálculo do valor das despesas primárias as transferências constitucionais, créditos extraordinários, despesas da Justiça Eleitoral sem caráter de recorrência em função das eleições e majoração dos custos com empresas públicas não dependentes (art. 107, §6).

A previsão de revisão do regime fiscal concretizado pela EC o 95 é para o décimo exercício financeiro após 2017 (art. 108 do ADCT), e, a não observância dos limites impostos pode gerar consequências de caráter punitivo, as quais se encontram descritas dentro do artigo 109 (BRASIL, 2017, p. 232).

A justificativa para a EC no 95 fora apresentada fundamentada no objetivo de se alcançar a contenção da instabilidade fiscal na qual foi colocado o Governo Federal (BRASIL, 2016), restaurando a longo prazo a sustentabilidade das contas públicas. Nas razões de propositura da PEC, restou registrado ainda que "ações para dar sustentabilidade às despesas públicas não são um fim em si mesmas, mas 


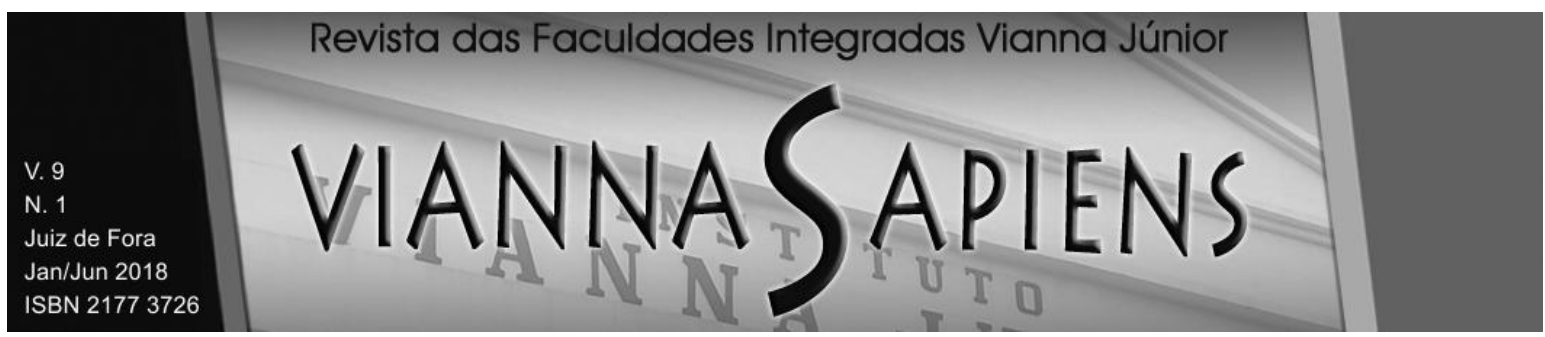

o único caminho para a recuperação da confiança, que se traduzirá na volta do crescimento" (BRASIL, 2016, p. 4), raciocínio resultado de uma relação direta entre os problemas fiscais do Governo Federal com o aumento das despesas primárias entre os anos de 2008 e 2015 acima da inflação.

Explicadas as linhas gerais do novo regime fiscal, devota-se agora a discussão dos reflexos do novo regime sobre as políticas públicas de acesso à água, de maneira pormenorizada no Programa Cisternas, que assume função instrumental na concretização do direito fundamental à água e da Agenda 2030.

É necessário partir da premissa estabelecida por Cass Sunstein e Stephen Holmes (2000) de que todo direito tem um custo, devendo ser financiado pelo Estado. Em relação à água, por mais que considerada como recurso natural de caráter público, o custo é inevitável.

Especialmente no Semiárido a garantia do acesso à água envolve um custo particularmente acentuado em função da seca, que não pode ser vencida totalmente, exigindo desta forma que sejam desenvolvidas tecnologias que permitam a sobrevivência dos indivíduos nos longos períodos de estiagem. É nesse ponto que o financiamento do direito a água (ODS 6) se torna claro: o Estado precisa investir em formas de captação de água para consumo humano e produção dentro do Semiárido como forma de proteger a dignidade dos cidadãos brasileiros.

Sem o acesso à água (ODS 6), outros direitos estarão em risco, como a saúde, alimentação, moradia, qualidade de vida e o trabalho, que também se configuram como orientações de desenvolvimento sustentável pela Agenda 2030. De acordo com o boletim de informações climáticas do INPE/CPTEC (2017), considerando as condições de atmosfera e do oceano, conjugadas com prognósticos feitos a partir de modelos dinâmicos e estocásticos de previsão de clima, na Região Nordeste - que engloba área semiárida, o nível de chuva tende a ser abaixo do normal nos últimos meses de 2017 e no período chuvoso de 2018, o que não destoa das previsões feitas em anos anteriores (CPTEC, 2017).

É fundamental que o Estado invista permanentemente em programas que viabilizem o acesso à água no semiárido brasileiro, especialmente na zona rural, que 


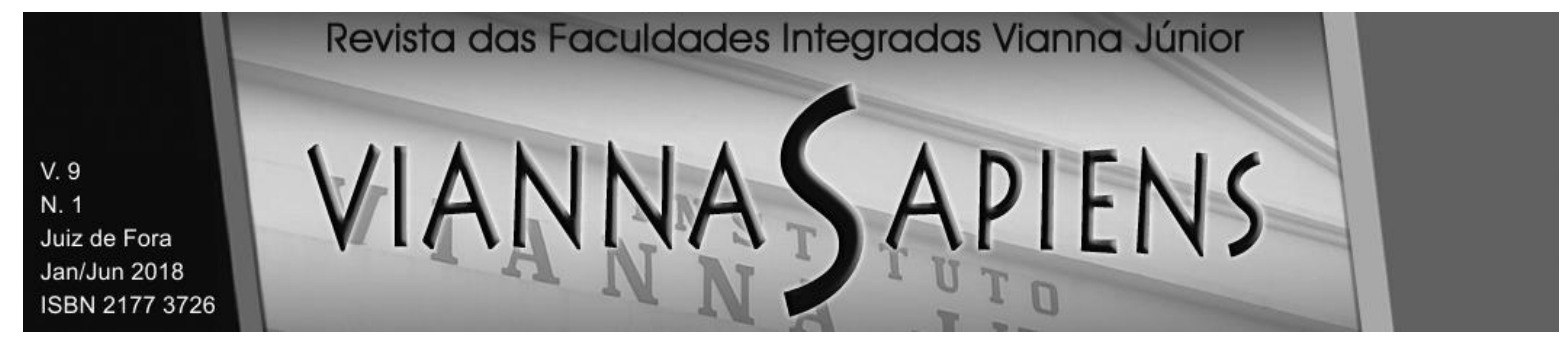

concentra uma camada pobre da população brasileira e que depende da ação do Estado, notadamente interventor na esfera social.

O Programa Cisternas constitui uma forte política pública na promoção do acesso à água pelas famílias de baixa renda da zona rural, atingidas pela seca ou falta regular de chuva, sendo o Semiárido uma prioridade do programa.

De acordo com o Ministério do Desenvolvimento Social (2016, p. 01) o Programa Cisternas busca:

Promover a convivência com a escassez de chuva, característica do clima na região, utilizando principalmente a tecnologia de cisternas de placas, reservatórios que armazenam água de chuva para utilização nos oito meses de período mais crítico de estiagem na região.

Pelo fato de ser uma política pública voltada para a convivência com a escassez, é lógico que os investimentos devem ser regulares e capazes de arcarem com a manutenção das cisternas já existentes, a construção de novas cisternas e criação de tecnologias de captação de água para o consumo humano.

A Articulação para o Semiárido (ASA Brasil) vem lutando desde 1999 pelo maior investimento nas políticas públicas de convivência com o Semiárido e combate à desertificação. Na Declaração do Semiárido (ASA, 1999), a instituição proclamou que uma das urgências na realidade rural do Semiárido brasileiro é o aumento e priorização de recursos para investimentos em infraestruturas social e econômica como forma de viabilizar condições dignas de sobrevivência na região caracteristicamente seca.

Anteriormente a 2013, algumas cisternas já haviam sido construídas, e, constatado o sucesso da nova forma de captação de água para o semiárido a atividade foi regulamentada, surgindo então o Programa Cisternas. No período de 2013 a 2014, os investimentos foram maciços. Até 2014, foram entregues mais de 500 mil cisternas, distribuídas entre o abastecimento familiar, escolar e agrícola, conforme destacou o Ministério do Desenvolvimento Social (2016). 


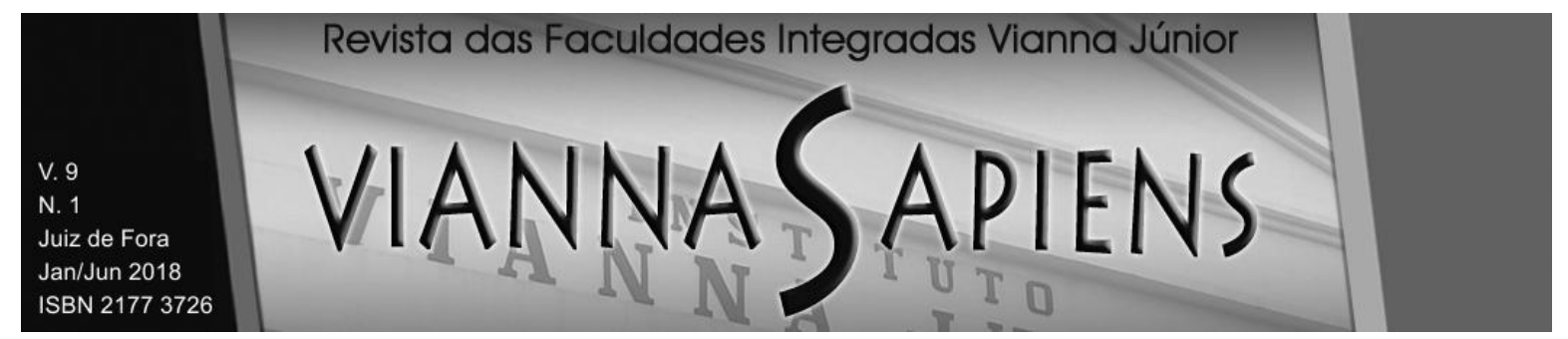

O Programa constrói três tipos de cisternas: a cisterna familiar, com capacidade para armazenamento de até 16 (dezesseis) mil litros de água potável e as cisternas escolar e para produção, ambas armazenando até 52 (cinquenta e dois) mil litros de água.

O crescimento do alcance do programa entre 2013 e 2017 foi exponencial, levando acesso à água para mais de um milhão de pessoas. Segundo o Relatório dos programas e ações do Ministério do Desenvolvimento Social em outubro de 2017 ultrapassou-se a marca de um milhão de cisternas, este número abarcando as cisternas familiares, escolares e de produção.

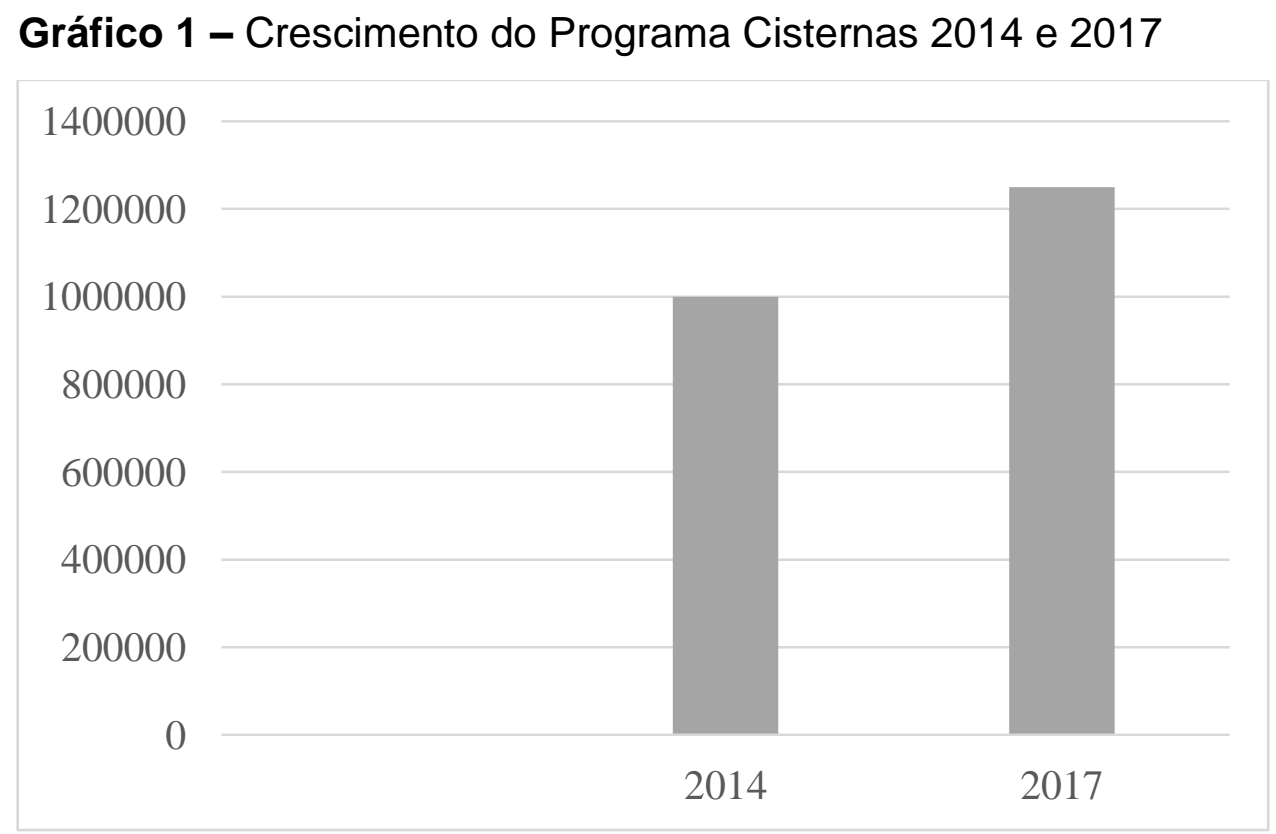

Fonte: Relatório de programas e ações do Ministério do Desenvolvimento Social (2017).

Diante da exposição gráfica do crescimento de implantações de cisternas no Semiárido, é possível constatar que a dita política pública percorreu um caminho de sucesso na promoção do acesso à água e implementação do ODS 6, contribuindo diretamente para a conformação de outros ODS's, como erradicação da pobreza (ODS1), fome zero e agricultura sustentável (ODS2), saúde e bem-estar (ODS3), dentre outros. 


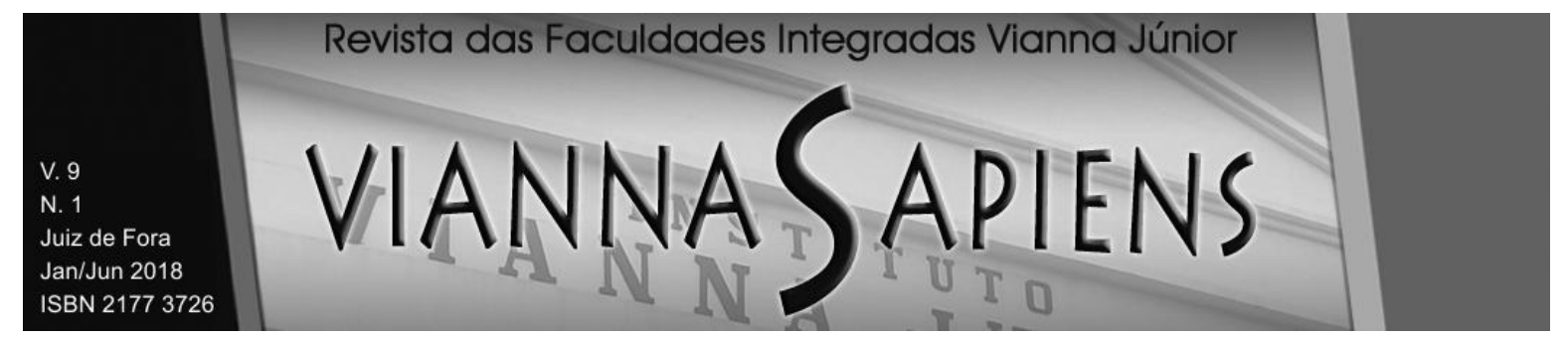

O sucesso e efetividade do Programa Cisternas foi tanto que 2017 ganhou o Prêmio Política Pública para o Futuro ONU, iniciativa do World Future Council (BORGES, 2017). A premiação considerou o Programa Cisternas por garantir o acesso à água para uma parte da população mais pobre do país que reside num bioma extremamente seco (IPEA, 2017), combatendo, além da estiagem, os efeitos mais nocivos dela: mortalidade infantil, fome e o êxodo.

Todavia, o sucesso do Programa Cisternas, bem como de qualquer política pública, depende de recursos disponíveis para seu financiamento. Reforçando o entendimento de Sunstein e Holmes (2000), todo direito tem um custo, o que não seria diferente com a água no Semiárido.

O financiamento do Programa Cisternas está inserido dentro do Programa de Segurança Alimentar e Nutricional do Governo Federal, referência 2069 na Lei Orçamentária, objetivo 0614 - contribuir para ampliar o acesso à água para consumo humano para a população pobre no meio rural e ação 8948 - apoio a Tecnologias Sociais de Acesso à Água para Consumo Humano e Produção de Alimentos na Zona Rural. Nesta altura faz-se mister trazer os orçamentos da União para o programa, objetivo e ação indicados acima. A observação das leis orçamentárias se dá entre 2013 e 2014.

Gráfico 2 - Recursos do Programa de Segurança Alimentar (2069)

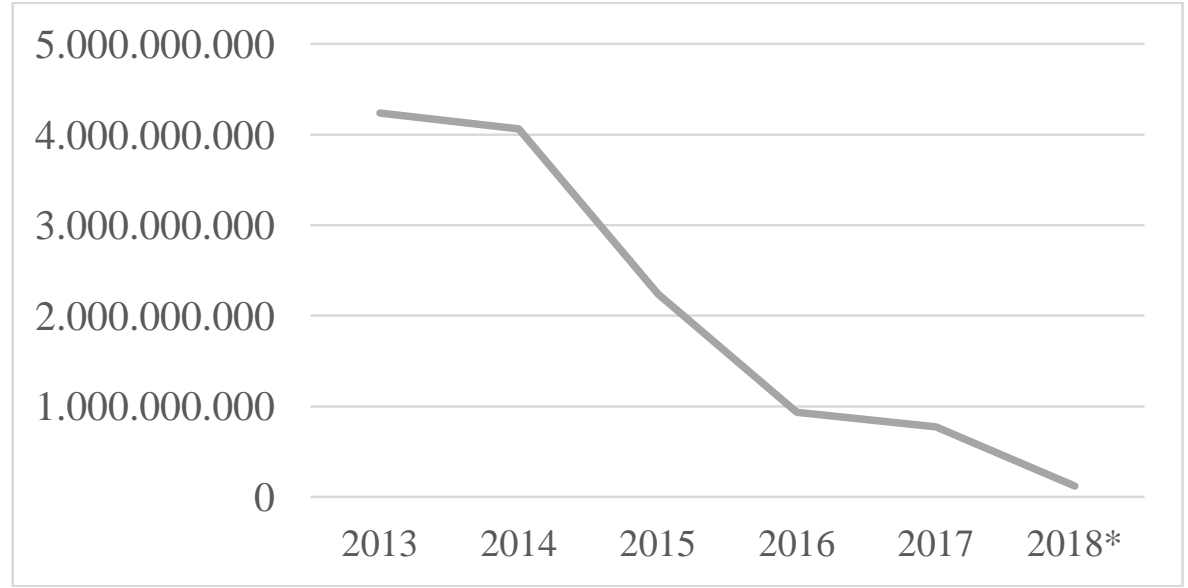

Fonte: Dados disponíveis no sítio eletrônico da Câmara dos Deputados (2017). 


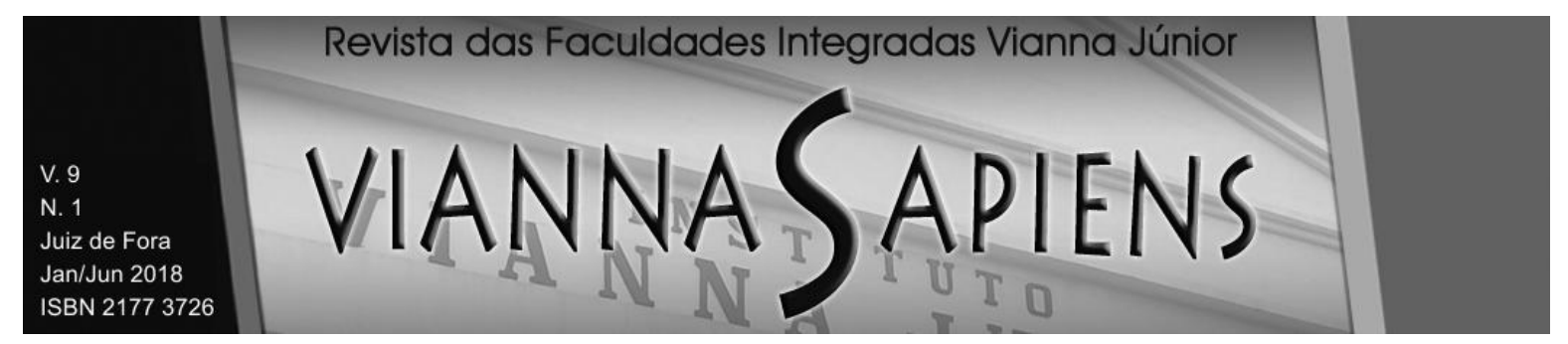

O que se infere da análise dos orçamentos de 2013 a 2018, é um aspecto problemático. Vale ressaltar que os números trazidos para o ano de 2018 não são definitivos, visto que o projeto de lei orçamentária está em tramitação, desse modo os valores dizem respeito ao texto apresentado pelo Executivo.

De 2013 a 2014, os recursos destinados ao Programa de Segurança Alimentar (2069) foram altos, ultrapassando a marca de 4 bilhões. Entre 2015 e 2017, houve uma perceptível queda na previsão orçamentária, porém, os recursos foram mantidos acima de 700 milhões, valor decerto considerado para a manutenção do referido programa, uma vez que grande volume de recursos fora previsto nos anos anteriores para implementação de uma política de segurança alimentar e nutricional forte. Em 2018, o valor de recursos previstos para o programa cai drasticamente, não chegando nem a 120 milhões. As curvas dos gráficos deixam clara a queda na previsão orçamentária.

No que toca a LOA de 2017, os recursos para o programa 2069 já foram limitados pelo valor das despesas primárias corrigidas pelo percentual de 7,2\%, seguindo o novo regime fiscal, culminando no valor de cerca de 780 milhões.

Já o PLO 2018, tem a previsão de pouco mais de 119 milhões, o que implica na redução de gastos com o programa. Utilizando a seguinte fórmula $T C=\frac{V f-V i}{V i}$, onde $T C$ equivale à taxa de crescimento, Vf ao recurso previsto no PLOA 2018 e Vi ao montante na LOA 2017, temos o seguinte número: $T C=\frac{119.431 .328-774.029 .586}{774.029 .586}=-$ 0,84, o que representa regressão no prognóstico de recursos da União para o Programa de Segurança Alimentar e Nutricional.

Analisando somente o Programa 2069, que abarca as ações de promoção do acesso à água na zona rural e o objetivo de captação de água para o consumo humano e produção, há grande impacto do novo regime fiscal. Em 2017, o impacto não foi sentido no espectro da LOA porque a correção, conforme a EC 95, partiu de um percentual de 7,2, valor acima da inflação acumulada no ano anterior, permitindo um crescimento real nas previsões orçamentárias. 


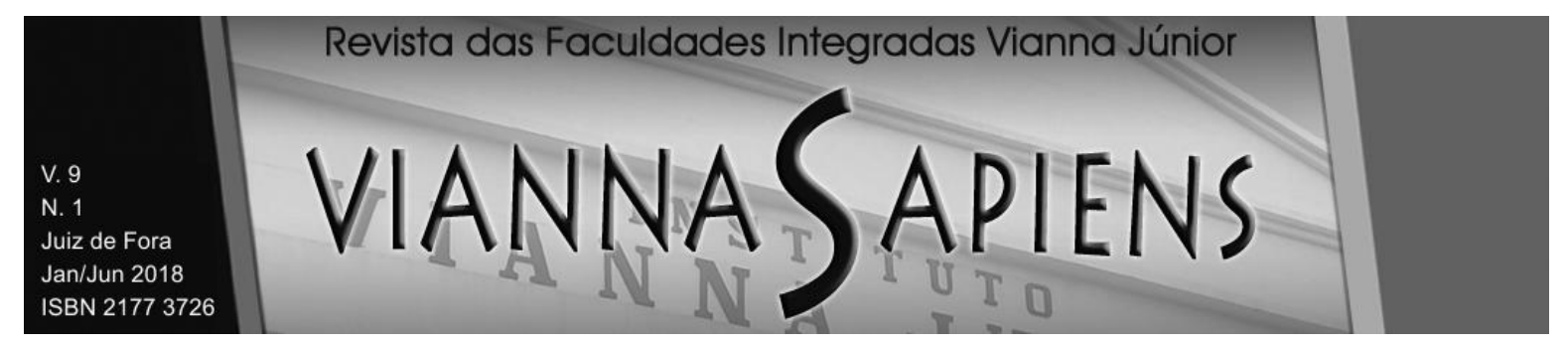

Contudo, em 2018, com a restrição de despesas - despesas primárias do exercício financeiro anterior atualizadas pelo IPCA - o crescimento na possibilidade de gastos é inexistente, não há crescimento real, somente acompanhamento da variação de preços constatada pelo índice atualizador, desaguando na necessidade de se realizar escolhas na alocação de recursos, escolhas de caráter político, o que terminou diminuindo de sobremaneira as verbas voltadas ao programa em discussão, o que implica reflexos também negativos na previsão de recursos para ampliar o acesso à água pela população pobre da zona rural e apoiar tecnologias sociais de captação de água potável para consumo humano e produção, impactando diretamente no Programa Cisternas. Os gráficos seguintes comprovam a repercussão hostil.

Objetivo 0614

Gráfico 3 - Recursos do Programa de Segurança Alimentar (2069) -

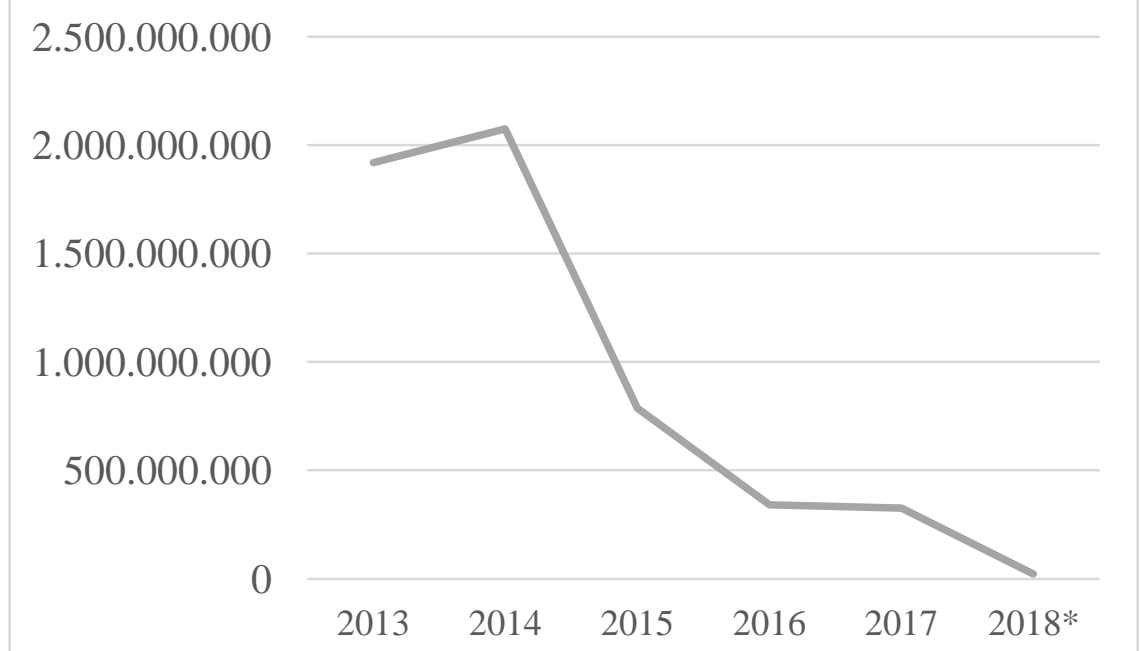

Fonte: Dados disponíveis no sítio eletrônico da Câmara dos Deputados (2017). 


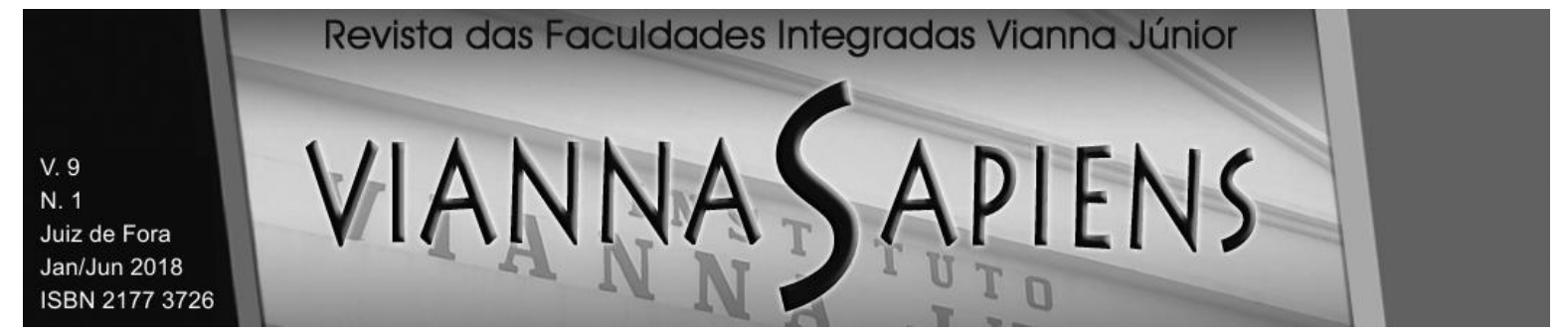

Gráfico 4 - Recursos do Programa de Segurança Alimentar (2069) Objetivo 0614 - Ação 8948

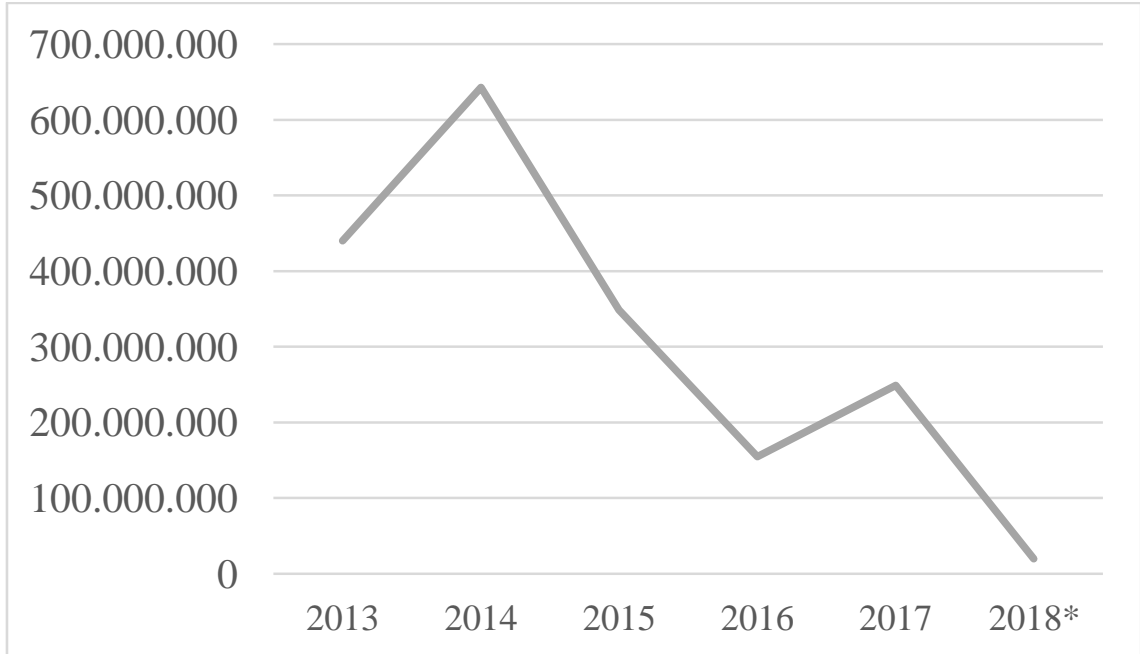

Fonte: Dados disponíveis no sítio eletrônico da Câmara dos Deputados (2017).

O regime fiscal vigente impôs limites aos gastos públicos e consequentemente aos recursos disponíveis para a seguridade social, gerando uma minoração violenta dos recursos disponíveis ao Estado para promover o acesso à água (ODS6): os recursos previstos para o Programa 2069 - Objetivo 0614 foram em média, entre os anos de 2013 e 2017, aproximadamente 1 bilhão. Em 2018, pelo PLOA, os recursos serão de $\mathrm{R} \$ 22.772 .828$ milhões.

Os recursos para financiamento do Programa Cisternas têm previsão na ação 8948 do Programa 2069 na LOA. De 2014 a 2017, os valores transferidos pela União para arcar com a política pública de acesso à água superaram o valor de um bilhão, a média das transferências nos últimos quatro anos foi de 379 milhões. $O$ PLOA de 2018, prevê apenas 20 milhões para a ação que custeia a política pública de promoção da água (MINISTÉRIO DO DESENVOLVIMENTO SOCIAL, 2017).

A meta 6.1 da ODS é até 2030 alcançar o acesso à água de forma universal e equitativa, porém, esta meta pode potencialmente não ser cumprida no Brasil visto que o regime fiscal inaugurado em 2017 perdura até 2036, ou seja, vinte anos com a possibilidade de não existir crescimento real nos recursos que viabilizam o Programa Cisternas, além de outros, que buscam promover o acesso à água por aqueles 


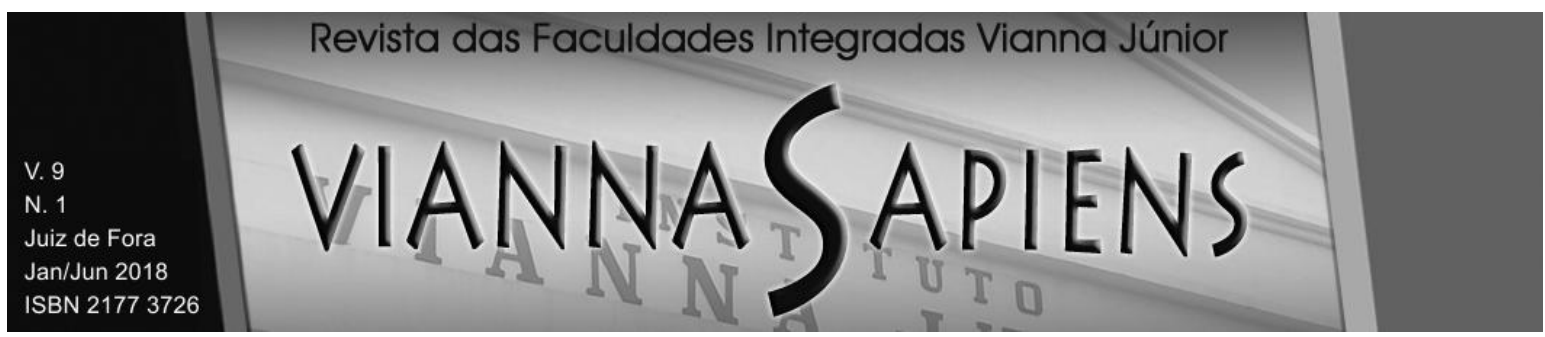

indivíduos que não têm condições suficientes a isso, seja em decorrência da condição de pobreza, seja pela ausência de chuva regular, como é no semiárido.

Admitindo a convivência, dentro da Constituição de 1988, dos aspectos social e financeiro, é possível afirmar que neste caso, a Constituição Financeira tende a não respeitar a Constituição Social (TORRES, 2014). O orçamento da seguridade social, vinculado aos fins de concretização dos direitos fundamentais, protegendo o cidadão dos perigos próprios da vida e conservando sua dignidade (TORRES, 2000), torna-se frágil.

A partir dos ensinamentos de José Casalta Nabais (2011), é possível afirmar que o desenvolvimento sustentável, para além dos aspectos econômico, social e ambiental, possui uma face oculta, que consiste nos compromissos e custos que estão atrelados à sua concretização, desta feita é preciso discutir, no contexto brasileiro com o funcionamento de um regime fiscal que limita os gastos públicos, como se pode fazer a alocação de recursos dentro do planejamento orçamentário do Estado sem prejudicar a concretização de direitos fundamentais, como a água, por exemplo, contribuindo para o desenvolvimento sustentável e cumprimento da Agenda 2030.

É preciso se discutir democraticamente com a população brasileira as regras orçamentárias, uma vez que elas se revestem de uma dimensão jurídico-política, constituindo um programa político em números vinculados a determinações legais e constitucionais, não podendo ser um paradoxo (FREITAS, 2011), em outros termos, constituindo um programa político financeiro do Estado violando as disposições constitucionais, inviabilizando a conformação de direitos indispensáveis ao ser humana investido de dignidade.

Suzana Tavares da Silva (2011), ao tratar dos parâmetros para um ajuste fiscal em tempos de crise por exigência de instituições globais preocupadas com a solvência dos estados, explica que as medidas de reequilíbrio fiscal devem obedecer à universalidade, ou seja, todos devem ser afetados diretamente pelas medidas de caráter limitadoras adotadas por determinado estado. Então, pergunta-se: por que há, com o novo regime fiscal, grande possibilidade - indicada pela análise dos 


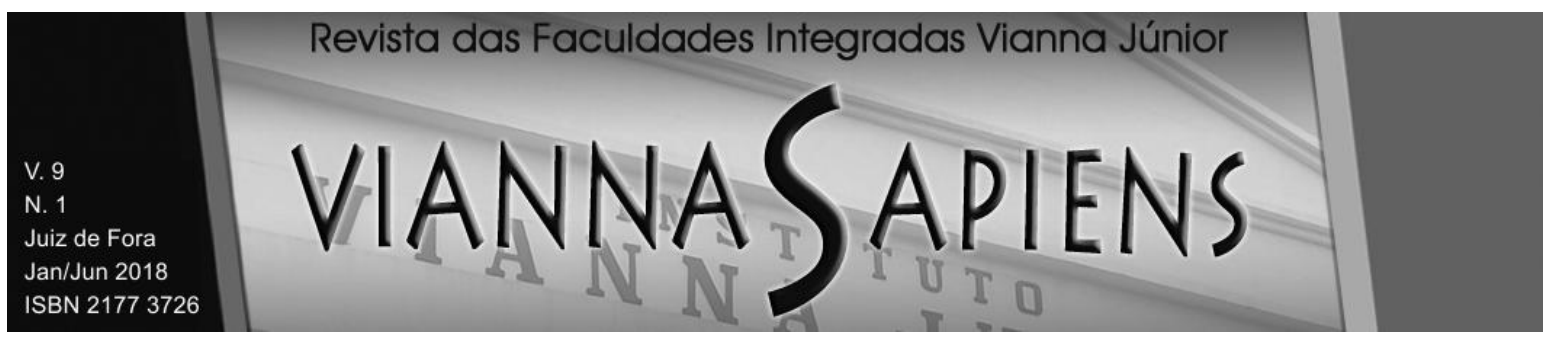

orçamentos feita nesse estudo - de impactos negativos no financiamento do Programa Cisternas, que promove o acesso à água, porém, a EC 95, inserindo o art. 109, §2º , II no ADCT, só suspende a possibilidade de concessões e ampliações de benefícios e incentivos tributários em casos de descumprimento do teto imposto? Ricardo Lobo Torres (2000) ensina que os benefícios tributários concedidos possuem o mesmo efeito de uma despesa.

\section{CONCLUSÃO}

A água constitui direito fundamental dos brasileiros. Adotando interpretações sistemática e teleológica da norma constitucional, conjugando os artigos 3ำ, 170, VI e 225, extrai-se da Constituição Federal de 1988 o princípio do desenvolvimento sustentável, que impõe ao Estado a persecução de um desenvolvimento nacional saudável alinhando crescimento econômico, ambiental e social. Decorrente do dito princípio, em função da clausula de abertura material do art. $5, \S 2^{\circ}$ da CF, a água surge como direito, indispensável ao desenvolvimento sustentável e a dignidade dos cidadãos, sendo reconhecida inclusive como um Objetivo para o Desenvolvimento Social (ODS 6) na Agenda 2030.

O Programa Cisternas, regulamentado especificamente em 2013, constitui uma política pública para o acesso à água de sucesso. Se distingue de outras porque leva a água para famílias pobres do Semiárido brasileiro, que não têm condições de, por si, conseguirem a água necessária para consumo ou produção, seja em decorrência da capacidade econômica, seja em função da irregularidade de chuvas.

Não obstante, a promoção do acesso à água no Semiárido demanda a previsão de recursos para efetivação da política pública respectiva, há um custo por trás da consolidação da água (ODS 6). Entretanto, o novo regime fiscal brasileiro, inaugurado com a Emenda Constitucional n 95, põe limites aos gastos primários da União, que financia o Programa. 


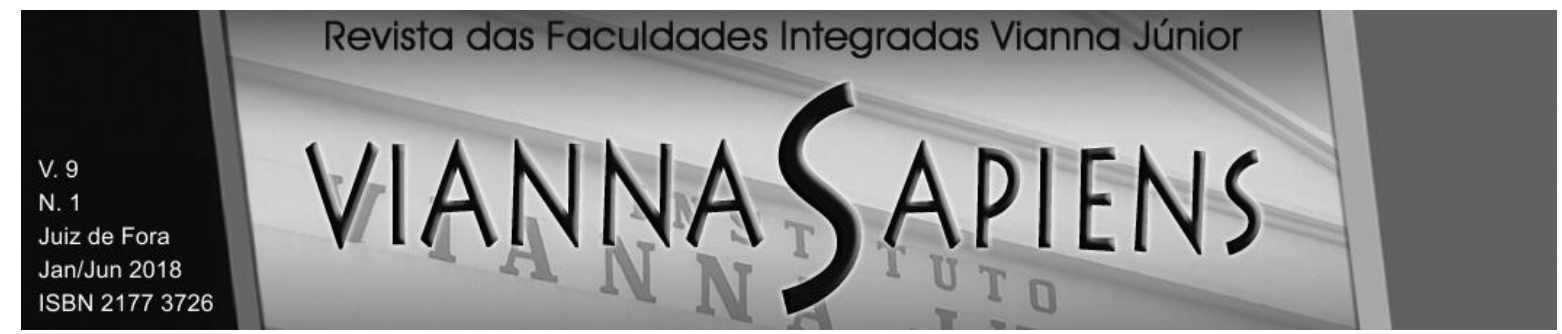

A imposição de um limite para os gastos públicos não é, à primeira vista, medida negativa, é preciso que haja equilíbrio entre as receitas e despesas do Estado. Mas o que acontece é a limitação geral das despesas primárias e consequentemente limitação de recursos, que a partir de 2018 passam a ser corrigidos pelo IPCA, índice que mede o valor da inflação acumulada no ano anterior, o que implica em um crescimento que não é real, obrigando a União a repensar o processo de alocação de recursos e suas prioridades.

Analisado as LOAS de 2013 a 2017 e o PLOA 2018, observa-se que os valores destinados ao Programa de Segurança Alimentar e Nutricional (2069) foram consideráveis até 2017, mas em 2018 sofre grande queda na previsão, o que repercute no objetivo 0614 do orçamento - ampliação e promoção do acesso à água para famílias pobres da zona rural - e na ação 8948 - apoio a novas tecnologias sociais para captação de água para consumo e produção.

Portanto, o novo regime fiscal representa perigo aos avanços na promoção do acesso à água por meio do Programa Cisternas, o que poderá ser identificado a partir das escolhas feitas dentro da lei orçamentária anual, pondo em risco o cumprimento da meta 6.1 da ODS 6 , que é alcançar o acesso à água de forma universal e equitativa em trinta anos, uma vez que o novo regime perdura até 2036.

\section{EAU (ODS 6), PROGRAMME CISTERNS ET NOUVEAU RÉGIME FISCAL BRÉSILIEN}

\section{RÉSUMÉ}

Ces écrits analysent la configuration de l'eau comme un droit fondamental du citoyen, le programme Cisternas comme un instrument pour la réalisation de ce droit dans le semi-aride brésilien et la relation entre le nouveau régime fiscal et la politique publique d'accès à l'eau. L'objectif est d'identifier les effets du régime fiscal en 


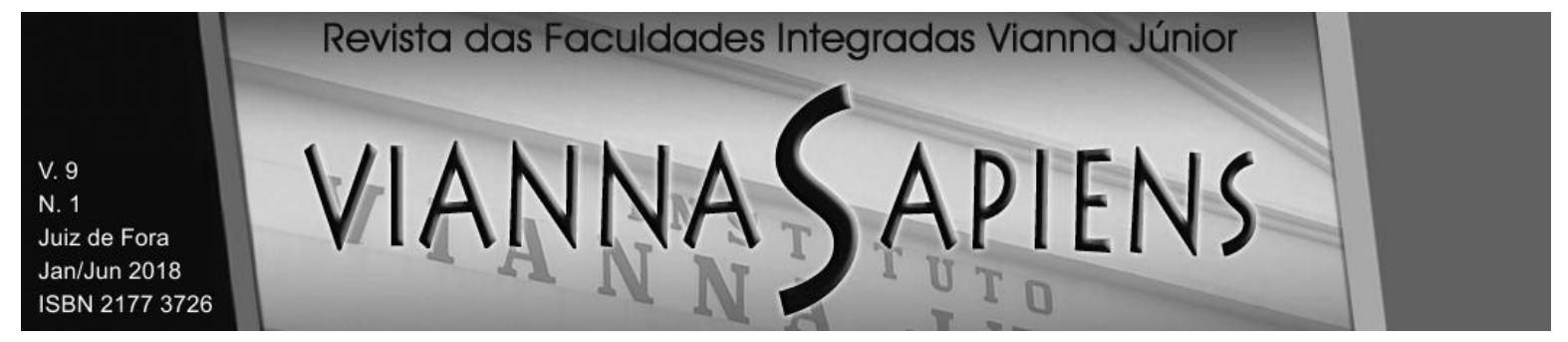

vigueur dans le programme Cisternas. Nous utilisons une méthode essentiellement qualitative, utilisant des techniques de recherche bibliographique et documentaire, ainsi qu'une analyse mathématique des budgets de l'Union entre 2013 et 2018. On en déduit que le programme Cisternas, en fonction de l'allocation des ressources dans la loi budgétaire annuelle, dans le nouveau régime fiscal, pourrait être affaiblie, entravant les progrès dans la promotion de l'accès à l'eau par les familles pauvres dans les zones rurales dans la région semi-aride brésilienne.

MOTS-ClÉS: EAU. PROGRAMme DE CISTERNAS. BUDGET. NOUVEAU REGIME FISCAL.

\section{REFERÊNCIAS}

ALEXY, Robert. Direitos fundamentais no Estado Constitucional Democrático.

Revista de Direito Administrativo, Rio de Janeiro, v. 217, p. 55-66, jul. 1999. ISSN 2238-5177. Disponível em:

<http://bibliotecadigital.fgv.br/ojs/index.php/rda/article/view/47413>. Acesso em: 03 nov. 2017.

ASA. Declaração do semiárido: propostas da articulação no semiárido brasileiro para a convivência com o semiárido e combate à desertificação. Disponível em: http://www.asabrasil.org.br/images/UserFiles/File/DECLARACAO DO SEMIARIDO.pdf. Acesso em: 16 nov. 2017.

BIRNFELD, Carlos André. Compromissos constitucionais do Poder Público brasileiro com a proteção do meio ambiente sob a perspectiva dos deveres-poderes de um Estado a serviço da cidadania e da proteção ambiental. In: MIRANDA, Jorge (Coord). Diálogo ambiental, constitucional e internacional. Rio de Janeiro: Lumen Juris, 2015.

BONAVIDES, Paulo. Do estado liberal ao estado social. 1. Ed. São Paulo: Malheiros, 2013. 


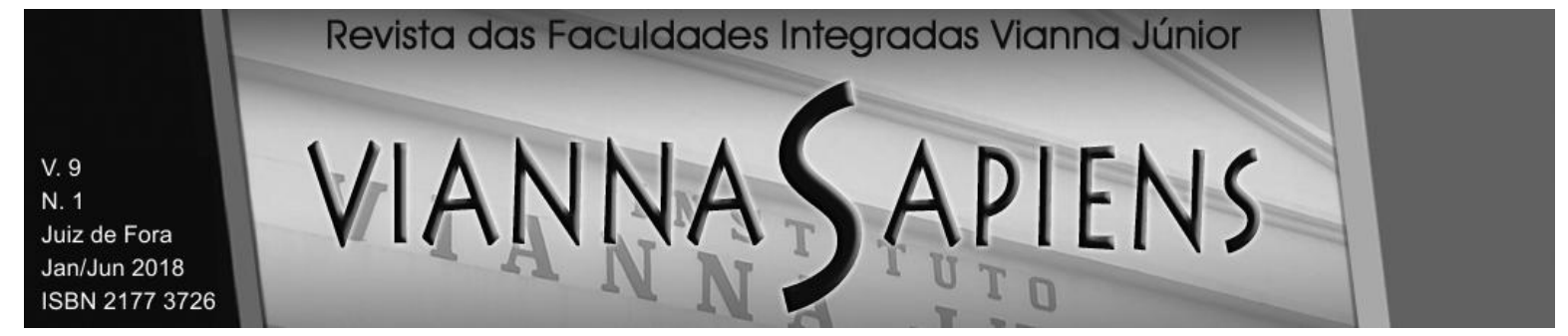

BORGES, Nina. Programa Cisternas ganha Prêmio de Política para o Futuro da ONU. Act!onaid. 2017. Disponível em:< http://actionaid.org.br/noticia/programacisternas-ganha-premio-de-politica-para-o-futuro-da-onu/>. Acesso em: 24 nov. 2017.

BRASIL. Constituição da República Federativa do Brasil de 1988. Brasília: Câmara dos Deputados, Edições Câmara, 2017.

Lei 9.433 de 8 de janeiro de 1997. Institui a Política Nacional de Recursos Hídricos, cria o Sistema Nacional de Gerenciamento de Recursos Hídricos. Disponível em: < http://www.planalto.gov.br/ccivil 03/leis/L9433.htm>. Acesso em: 04 nov. 2017.

Medida Provisória 619 de 6 de junho de 2013. Institui o Programa nacional de apoio à captação de água de chuva e outras tecnologias sociais de acesso à água - Programa Cisternas. Disponível em: < http://www.planalto.gov.br/ccivil 03/ ato2011-2014/2013/Mpv/mpv619.htm >. Acesso em: 04 nov. 2017.

Nova delimitação do semiárido do brasil, com 1.189 municípios em nove estados: Alagoas, Bahia, Ceará, Minas Gerais, Paraíba, Pernambuco, Piauí, Rio Grande do Norte e Sergipe. Disponível em: < http://www.mi.gov.br/documents/1406782/0/NOVA+DELIMITA\%C3\%87\%C3\%830+ DO+SEMI\%C3\%81RIDO+DO+BRASIL++LISTA+DE+MUNIC\%C3\%8DPIOS.pdf/db072877-c3c7-42f2-979a-338c6c460aab>. Acesso em: 15 nov. 2017.

Proposta de emenda à Constituição no 241 de 16 de junho de 2016. Altera o Ato das disposições constitucionais transitórias para instituir o novo regime fiscal. Disponível em: < http://www.camara.gov.br/proposicoesWeb/prop mostrarintegra;jsessionid=97CDEF 95CC5D9692D922B1E755186BA2.proposicoesWebExterno2? codteor $=1468431 \&$ file name=Tramitacao-PEC+241/2016>. Acesso em: 08 nov. 2017.

BUCCI, Maria Paula Dallari. O conceito de política pública em Direito. In: BUCCI, Maria P. D. (Coord.). Políticas públicas: reflexões sobre o conceito jurídico. São Paulo: Saraiva, 2006, p. 39. 


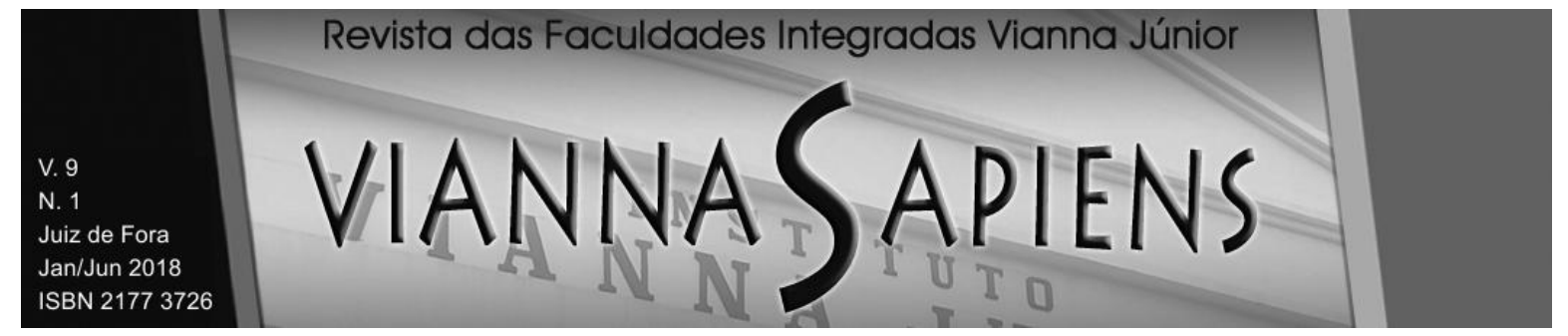

CÂMARA DOS DEPUTADOS.LOA - Lei orçamentária anual. Disponível em: http://www2.camara.leg.br/orcamento-da-uniao/leis-orcamentarias/loa. Acesso em: 24 nov. 2017.

CENTRO REGIONAL DE INFORMAÇÕES DA ONU. Assembleia Geral declara o acesso a água potável e ao saneamento um direito humano. Disponível em: < http://www.unric.org/pt/actualidade/28767-assembleia-geral-declara-o-acesso-aagua-potavel-e-ao-saneamento-um-direito-humano>. Acesso em: 03 nov. 2017.

CPTEC. Infoclima. Disponível em: < http://infoclima1.cptec.inpe.br/>. Acesso em: 15 nov. 2017.

DIEESE. Pec no241/2016: o novo regime fiscal e seus impactos. Disponível em: < https://www.dieese.org.br/notatecnica/2016/notaTec161 novoRegimeFiscal.pdf>. Acesso em: 05 nov. 2017.

DYE, Thomas. Understanding public policy. Englewood Cliffs, NJ: Prentice Hall, 1984

FINGER, Ana Claúdia. Licitações sustentáveis como instrumento de política pública na concretização do direito fundamental ao meio ambiente sadio e ecologicamente equilibrado. In: BLANCHET, Luiz Alberto et al (Coord.). Estado, direito e políticas públicas. Curitiba: Ithala, 2014.

FREITAS, Juarez. Sustentabilidade: direito ao futuro. Belo Horizonte: Fórum, 2011.

INPE/CPTEC. Boletim de informações climáticas do INPE/CPTEC. Ano 24. Outubro de 2017. Número X. Disponível em: < http://infoclima.cptec.inpe.br/ rinfo/pdf infoclima/201710.pdf>. Acesso em: 15 nov. 2017.

IPEA. $O$ atlas da vulnerabilidade social nos municípios e regiões metropolitanas brasileiras. Disponível em:< http://ivs.ipea.gov.br/index.php/pt/planilha> . Acesso em: 24 nov. 2017. 


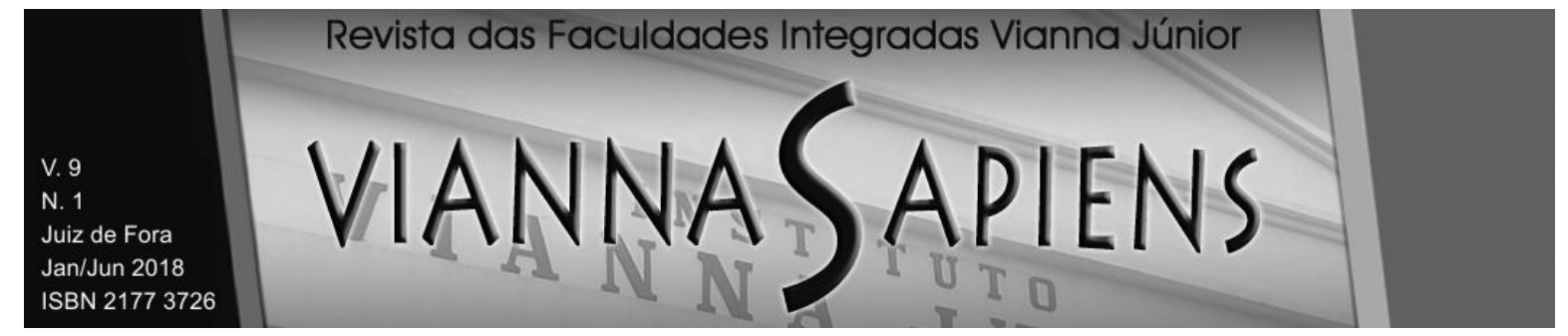

JHERING, Rudolf von. A finalidade do direito. Campinas: Bookseller, 2002.

MATIAS, João Luis Nogueira. Instrumentos econômicos, financiamentos e mudanças climáticas: o regime jurídico dos bens como forma de proteção ao meio ambiente. In: ARAÚJO, A.; BELCHIOR, Germana P. N.; VIEGAS, Thais E. de S. (Orgs.). Os impactos das mudanças climáticas no nordeste brasileiro. Fortaleza: SINTAF, 2016, p. 352.

MINISTÉRIO DO DESENVOLVIMENTO SOCIAL. Decreto 8.038 de 4 de julho de 2013. Regulamenta o Programa nacional de apoio à captação de água de chuva e outras tecnologias sociais de acesso à água - Programa Cisternas, e dá outras providências. Disponível em: <

http://www.planalto.gov.br/ccivil 03/ ato2011-2014/2013/Decreto/D8038.htm>. Acesso em: 04 nov. 2017.

. Lei no 12.873 de 24 de outubro de 2013. Institui o Programa nacional de apoio à captação de água de chuva e outras tecnologias sociais de acesso à água - Programa Cisternas. Disponível em: < http://www.planalto.gov.br/ccivil 03/ ato2011-2014/2013/Lei/L12873.htm>. Acesso em: 04 nov. 2017.

Programa cisternas. Disponível em: < http://mds.gov.br/assuntos/seguranca-alimentar/acesso-a-agua-1/programacisternas >. Acesso em: 04 nov. 2017.

Relatório de programas e ações do MDS. Disponível em:< https://aplicacoes.mds.gov.br/sagi/ri/relatorios/mds/index.php\#cisternas >. Acesso em: 24 nov. 2017.

. Transferências da ação 8948. MDS: Secretaria Nacional de Segurança Alimentar e Nutricional, 2017.

NABAIS, José Casalta. Da sustentabilidade do estado fiscal. In: NABAIS, José Casalta. SILVA, Suzana Tavares da. Sustentabilidade fiscal em tempos de crise. Coimbra: Ed. Almedina, 2011. 


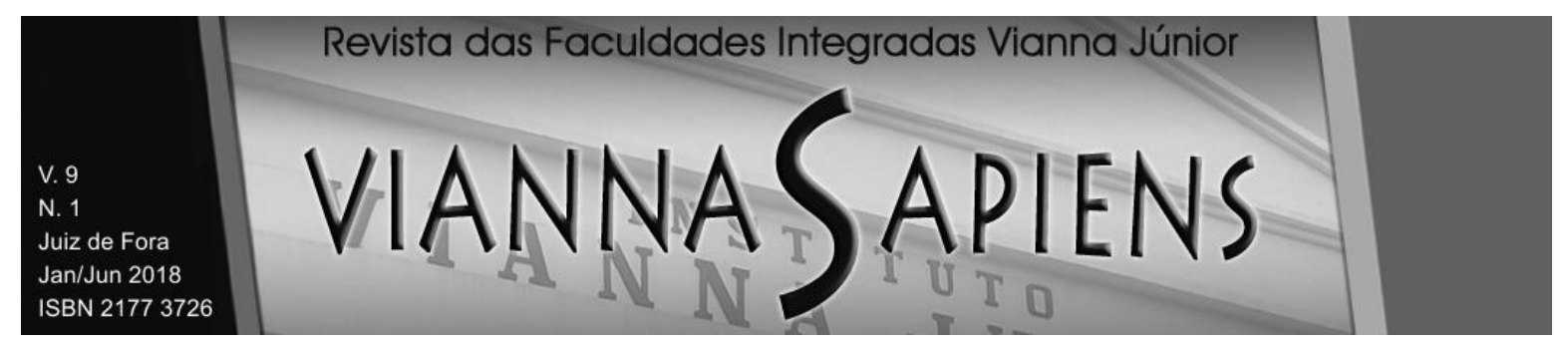

ORGANIZAÇÃO DAS NAÇÕES UNIDAS. A ONU e o meio ambiente. Disponível em: <https://nacoesunidas.org/acao/meio-ambiente/>. Acesso em: 04 nov. 2017.

SAVIGNY, Friedrich Carl von. Los fundamentos de la ciencia jurídica. In: SAVIGNY, Friedrich von. La ciencia del derecho. Buenos Aires: Losada, 1949.

SILVA, Suzana Tavares da. Sustentabilidade e solidariedade em tempos de crise. In: NABAIS, José Casalta. SILVA, Suzana Tavares da. Sustentabilidade fiscal em tempos de crise. Coimbra: Ed. Almedina, 2011.

SUSTEIN, Cass.; HOLMES, Stephen. The cost of rigths: why liberty depends on taxes. W. W. Noton: New York, 2000.

TORRES, Heleno T. Direito constitucional financeiro: toeira da constituição financeira. São Paulo: Editora Revista dos Tribunais, 2014.

TORRES, Ricardo Lobo. Tratado de direito constitucional financeiro e tributário: o orçamento na Constituição. Rio de Janeiro: Renovar, 2000.

Recebido em 11/04/2018

Publicado em 13/08/2018 